\title{
TRMM Satellite Algorithm Estimates to Represent the Spatial Distribution of Rainstorms
}

\author{
Marina Patrick ${ }^{1, a}$, Yau Seng Mah ${ }^{1}$, Frederik Josep Putuhena ${ }^{2}$,Yin Chai Wang ${ }^{1}$ and Onni Suhaiza Selaman ${ }^{1}$ \\ ${ }^{1}$ Universiti Malaysia Sarawak (UNIMAS), Jalan Datuk Mohammad Musa, 94300 Kota Samarahan, Sarawak, Malaysia \\ ${ }^{2}$ Universitas Pancasila, Jl. Srengseng Sawah, Jagakarsa, Jakarta Selatan 12640, Indonesia
}

\begin{abstract}
On-site measurements from rain gauge provide important information for the design, construction, and operation of water resources engineering projects, groundwater potentials, and the water supply and irrigation systems. A dense gauging network is needed to accurately characterize the variation of rainfall over a region, unfitting for conditions with limited networks, such as in Sarawak, Malaysia. Hence, satellite-based algorithm estimates are introduced as an innovative solution to these challenges. With accessibility to dataset retrievals from public domain websites, it has become a useful source to measure rainfall for a wider coverage area at finer temporal resolution. This paper aims to investigate the rainfall estimates prepared by Tropical Rainfall Measuring Mission (TRMM) to explain whether it is suitable to represent the distribution of extreme rainfall in Sungai Sarawak Basin. Based on the findings, more uniform correlations for the investigated storms can be observed for low to medium altitude (>40 MASL). It is found for the investigated events of Jan 05-11, 2009: the normalized root mean square error $(\mathrm{NRMSE}=36.7 \%$ ); and good correlation $(\mathrm{CC}=0.9)$. These findings suggest that satellite algorithm estimations from TRMM are suitable to represent the spatial distribution of extreme rainfall.
\end{abstract}

\section{Introduction}

The understanding of spatial distribution for rainfall, especially during extreme conditions is important for water resources planning, river basin management, hydrological and ecological applications, assessment of groundwater potential, and the design of water supply and irrigation systems $[1,2]$.

In-situ measurements from rain gauge have been implied as the ground truth observations where it yields relatively reliable point records of precipitation [3]. However, the precipitation depth collected by the rain gauge is affected by local turbulence, variations in vertical velocities, and rapid short-term fluctuations in the moisture that flow into the area above the rain gauge [4]. There is also the possibility of sampling errors when measuring these instabilities, particularly when extrapolating the probable maximum yield. In addition, a dense network of rain gauges is also required to accurately characterize the variation of rainfall pattern over a region. Unfortunately, this is not an ideal condition for areas with a limited network or sparse distribution of gauging and meteorological stations in the tropics, such as in Sarawak, Malaysia. This has resulted to engineering and technological challenges in understanding the spatial distribution of rainfall especially during storm events.

Hence, remotely sensed satellite-based precipitation (SBP) estimates are introduced as an innovative solution

\footnotetext{
a Corresponding author: 15010110@siswa.unimas.my
}

to these challenges. With the free accessibility to retrieve this dataset from public domain websites, it has become a useful data source to measure rainfall for a wider coverage area at finer temporal resolution.

Among various SBP products is the Tropical Rainfall Measuring Mission (TRMM). The TRMM system is the pioneer of satellite-based program mission specifically to observe precipitation in the tropics. Operating at a lowaltitude orbit of $402 \mathrm{~km}$ and declination of $35^{\circ}$ to the equator, the satellite orbits the globe 16-times over the tropical regions within the 24-hour duration. TRMM Multi-Satellite Precipitation Analysis (TMPA) provides a sequential scheme of combined rainfall estimates from multiple satellites, which is also calibrated with onground rain gauge observations. TMPA has $0.25^{\circ} \times 0.25^{\circ}$ scale of spatial resolution and temporal resolution of 3hourly scales over the tropical region between $50^{\circ} \mathrm{N}-50^{\circ}$ $\mathrm{S}[5]$.

Several studies have evaluated the different types of SBP products. For example, three SBP products: TMPA 3B42 real time (RT), TMPA 3B42 v7 and Climate Prediction Center Morphing Technique (CMORPH) were assessed to analyze the seasonal rainfall variability in Pakistan [6]. The TMPA 3B42 v7, its predecessor v6, and the North-Western South America Retrospective Simulation (OA-NOSA30) in the Pacific-Andean region of Ecuador and Peru were evaluated in order to compensate for data scarcity [7], whereby the 
performance of SBP products: TMPA 3B42 V6, V7 and RT, the NOAA/Climate Prediction Center Morphing technique (CMORPH), Hydroestimator (HYDRO) and the Combined Scheme algorithm $(\mathrm{CoSch})$ were evaluated by [8]. The analysis was conducted in southern South America. In Malaysia, the performance of SBP products: TMPA 3B42 RT and v7, Global Precipitation Climatology Project (GPCP-1DD), Precipitation Estimation from Remotely Sensed Information using Artificial Neural Networks (PERSIANN-CDR), CMORPH and Asian Precipitation Highly Resolved Observational Data Integration towards Evaluation of the Water Resources (APHRODITE) were assessed by [9]. They maintained that TMPA 3B42 v7 has better accuracy to estimate rain with lower bias results. They also concluded that TMPA 3B42 products showed the closest estimations during flood events induced by heavy precipitation.

However, despite datasets calibration between ground observations and SBP products, discrepancies still do exist. Sampling frequency, the satellite's spatial and temporal resolution and width of swath, non-uniform field or sensor's view and the uncertainty to quantify the precipitation retrieval algorithm may attribute to these errors [10]. Furthermore, studies also found that modulating orographic and relief variations in higher ground elevations or mountainous regions could also affect SBP performance. For example, TRMM precipitation radar (PR) were evaluated over the mountainous regions in the southern of continental United States [11]. It was found large biases and low correlation in the satellite precipitation rates.

Thus, there is a need to evaluate the remote sensing satellite observations with ground surface of varying elevation in the tropics to verify its accuracy. Moreover, there has yet been any studies evaluating the suitability of the TRMM satellite algorithm estimates to represent the distribution of rainstorms especially during flood events in Sarawak. This paper's aim is to investigate the mentioned ground surface elevation on rainfall estimates prepared by TMPA 3B42 v7 on its suitability to represent the spatial distribution of extreme rainfalls in Sungai Sarawak Basin (SSB).

\section{Study area}

SSB is located in the south-western part of Sarawak state with an approximate coverage of $2,459 \mathrm{~km}^{2}$ comprising of 2 principal tributaries, namely Sungai Sarawak Kiri and Sungai Sarawak Kanan. The two rivers confluence at Batu Kitang while the main stem flows through the capital, Kuching City. Sungai Sarawak spreads over 120 $\mathrm{km}$ in length separating the capital into northern and southern regions, before finally flowing into the South China Sea [12]. The site is situated in the tropics between the latitude of $1^{\circ} 0^{\prime} \mathrm{N}$ and $2^{\circ} 0^{\prime} \mathrm{N}$ and longitude of $109^{\circ} 30^{\prime}$ $\mathrm{E}$ and $111^{\circ} 0^{\prime}$ E. Digital elevation model (DEM) of SSB are extracted from NASA's Shuttle Radar Topography Mission (SRTM) and the positions of the available rain gauge stations and the study area is depicted in Figure 1.
All year round, SSB experiences wet and humid climate, characterized by high annual rainfall, humidity, and temperature. There are two monsoon seasons experienced by the state, the North-East Monsoon (NEM), comes with heavy rainfall from November to March. Meanwhile, the lesser rainfall seasons, SouthWest Monsoon (SWM) occurs from May to September and two transition periods occur in April and October. Average rainfall varies between 3000 to $5500 \mathrm{~mm}$ annually and temperature fluctuates within the range of $20^{\circ} \mathrm{C}$ to $36^{\circ} \mathrm{C}$ [13-15].

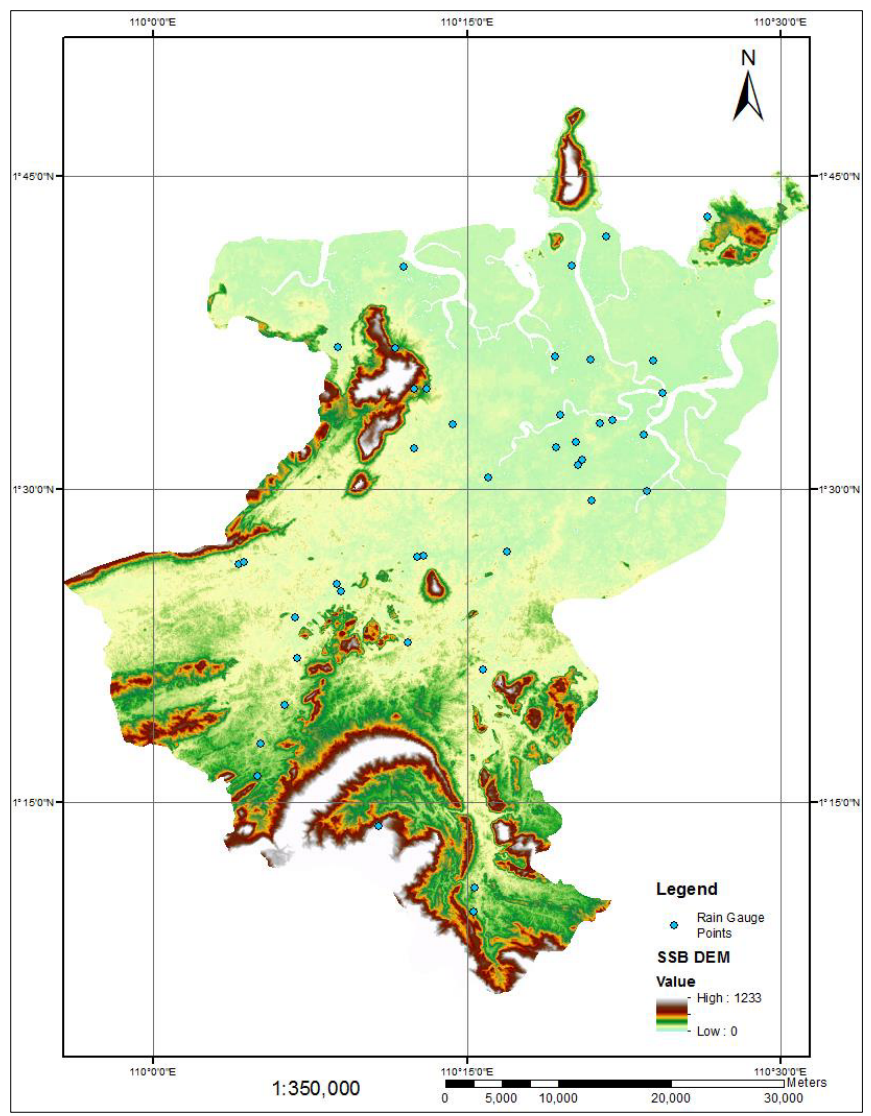

Figure 1. Locations of rain gauges over the DEM of SSB. The blue dot is representing the rain gauge point.

\section{Methods}

Rainfall Spatial Modelling is prepared using a Geographic Information System (GIS), whereby Table 1 summarizes the GIS thematic data layers, the data format or representation, and their sources applied in the research.

Table 1. GIS thematic data layers

\begin{tabular}{lll}
\hline Data Layer & $\begin{array}{l}\text { Data } \\
\text { Representation }\end{array}$ & Data Sources \\
\hline $\begin{array}{l}\text { Digital } \\
\text { elevation } \\
\text { model (DEM) }\end{array}$ & $\begin{array}{l}\text { 90m x 90m } \\
\text { resolution raster }\end{array}$ & $\begin{array}{l}\text { Shuttle Radar } \\
\text { Topography Mission } \\
\text { (SRTM) }\end{array}$ \\
Base map & JPEG Image file & $\begin{array}{l}\text { Topographic map of } \\
1: 240,000 \text { scale } \\
\text { collated from the }\end{array}$ \\
\hline
\end{tabular}


Department of

Irrigation and

Drainage (DID)

\begin{tabular}{|c|c|c|}
\hline \multicolumn{3}{|c|}{ Table 1. (continued) } \\
\hline $\begin{array}{l}\text { Precipitation } \\
\text { Accumulation } \\
\text { Maps }\end{array}$ & NetCDF & $\begin{array}{l}\text { TRMM Multi-satellite } \\
\text { Precipitation Analysis } \\
\text { (TMPA 3B42 v7) }\end{array}$ \\
\hline $\begin{array}{l}\text { Rain Gauge } \\
\text { Stations }\end{array}$ & Vector-point & $\begin{array}{l}\text { Department of } \\
\text { Irrigation and } \\
\text { Drainage (DID) }\end{array}$ \\
\hline
\end{tabular}

\subsection{Ground surface observations}

According to Sarawak Hydrological Station Inventory, there are 43 gauging stations available in SSB [16]. The current overall network density for the catchment area is about $57 \mathrm{~km}^{2}$ per gauge, which is relatively dense within the guideline by the World Meteorological Organization (WMO). For tropical zones, the suggested minimum density of rain gauge stations are $(600 \sim 900) \mathrm{km}^{2}$ and $(100 \sim 250) \mathrm{km}^{2}$ for flat areas and mountainous areas, respectively [17]. Nonetheless, the gauge density in SSB is below the ranges of the typical urban rain gauge catchments, which is one gauge per $(10 \sim 20) \mathrm{km}^{2}$ [18].

Hourly rainfall data collected from DID was screened through for outliers and any data that shows inconsistency was removed. Consequently, due to insufficient records, only 25 rain gauge stations were considered. Table 2 shows the details of the rain gauge stations such as the station names and the geographical coordinates of their respective locations.

Table 2. Details of selected rain gauge stations

\begin{tabular}{|c|c|c|c|c|c|}
\hline No. & $\begin{array}{l}\text { Station } \\
\text { Name }\end{array}$ & $\begin{array}{c}\text { Station } \\
\text { ID }\end{array}$ & $\begin{array}{l}\text { Lat } \\
/{ }^{\circ}\end{array}$ & $\begin{array}{c}\text { Lon } \\
/^{\circ}\end{array}$ & $\begin{array}{c}\text { El } \\
/ \\
\text { MASL }^{\mathbf{a}}\end{array}$ \\
\hline 1 & $\begin{array}{l}\text { Batu } \\
\text { Kitang }\end{array}$ & 1402047 & 1.45 & 110.28 & 60 \\
\hline 2 & $\begin{array}{l}\text { Kampung } \\
\text { Git }\end{array}$ & 1302078 & 1.36 & 110.26 & 25 \\
\hline 3 & $\begin{array}{l}\text { Kuching } \\
\text { Airport }\end{array}$ & 1403001 & 1.49 & 110.35 & 25 \\
\hline 4 & $\mathrm{Bau}$ & 1401005 & 1.42 & 110.15 & 55 \\
\hline 5 & Buan Bidi & 1301002 & 1.40 & 110.11 & 11 \\
\hline 6 & Krokong & 1301074 & 1.37 & 110.11 & 58 \\
\hline 7 & $\begin{array}{l}\text { Kampung } \\
\text { Monggak }\end{array}$ & 1301001 & 1.33 & 110.10 & 50 \\
\hline 8 & $\begin{array}{l}\text { Kampung } \\
\text { Opar }\end{array}$ & 1400001 & 1.44 & 110.07 & 30 \\
\hline 9 & $\begin{array}{l}\text { Siniawan } \\
\text { Water } \\
\text { Works }\end{array}$ & 1402001 & 1.45 & 110.21 & 40 \\
\hline
\end{tabular}

\begin{tabular}{llllll}
10 & $\begin{array}{l}\text { Buntal } \\
\text { DID }\end{array}$ & 1703001 & 1.70 & 110.36 & 2 \\
11 & $\begin{array}{l}\text { Kuching } \\
\text { Saberkas }\end{array}$ & 1503004 & 1.54 & 110.34 & 80 \\
\hline
\end{tabular}

Table 2. (continued)

\begin{tabular}{|c|c|c|c|c|c|}
\hline 12 & $\begin{array}{l}\text { Kuching } \\
\text { Third Mile }\end{array}$ & 1503083 & 1.52 & 110.34 & 25 \\
\hline 13 & Siol JPS & 1603002 & 1.60 & 110.35 & 10 \\
\hline 14 & $\begin{array}{l}\text { Telok } \\
\text { Assam }\end{array}$ & 1704013 & 1.72 & 110.44 & 5 \\
\hline 15 & Ulu Maong & 1503008 & 1.52 & 110.34 & 5 \\
\hline 16 & $\begin{array}{l}\text { Semariang } \\
\text { Fisheries }\end{array}$ & 1603001 & 1.61 & 110.32 & 2 \\
\hline 17 & Rampangi & 1603058 & 1.68 & 110.33 & 10 \\
\hline 18 & $\begin{array}{l}\text { Bako } \\
\text { Causeway }\end{array}$ & 1503001 & 1.60 & 110.40 & 13 \\
\hline 19 & $\begin{array}{l}\text { Sungai } \\
\text { China }\end{array}$ & 1601003 & 1.61 & 110.19 & 120 \\
\hline 20 & Matang & 1502026 & 1.58 & 110.21 & 120 \\
\hline 21 & $\begin{array}{l}\text { Sungai } \\
\text { Rayu }\end{array}$ & 1601001 & 1.61 & 110.15 & 5 \\
\hline 22 & $\begin{array}{l}\text { Kampung } \\
\text { Sagah }\end{array}$ & 1502003 & 1.53 & 110.21 & 39 \\
\hline 23 & Sebubut & 1502001 & 1.58 & 110.22 & 30 \\
\hline 24 & Padawan & 1102019 & 1.16 & 110.26 & 45 \\
\hline 25 & Semban & 1201076 & 1.23 & 110.18 & 460 \\
\hline
\end{tabular}

MASL $^{\mathrm{a}}$ is unit of elevation in meters above sea level

Flood disasters have been recurring in Sarawak, especially in Kuching City where significant floods were reported to occur in Kuching during February 2003, January 2004, and January 2009 [19]. Expectedly, all these events had occurred during the NEM season. According to the Annual Flood Report prepared by DID, continuous heavy rain influenced by the NEM season coincided with high tide that increased the Sungai Sarawak water level and thus causing massive floods. In addition, it was reported in [20] as to how the two episodes of extreme rainfall events in early $2009(8-11$ January \& 29 January) had caused severe flooding that had a statewide effect. It was known as the extreme year for Sarawak.

Therefore, this study is prompted to take the mentioned extreme rain events for the year 2003, 2004 and 2009 after further deliberation to investigate the distribution of rainstorms by means of spatial analysis. 


\subsection{Satellite-based precipitation}

TMPA 3B42 v7 rainfall dataset retrievals are obtained from the public domain website, (http://giovanni.sci.gsfc.nasa.gov/giovanni/).

The TRMM multi-satellite orbits the globe with a $35^{\circ}$ inclination to the equator. Therefore, the data is rearranged based on the Universal Traverse Mercator (UTM) geographical coordinate system with the datum of World Geodetic System of 1984 (WGS84). For mapping purposes, the reference coordinate system is projected to the Rectified Skew Orthomorphic (RSO) map projection system. The projected coordinate system is referred as the Timbalai 1948 RSO Borneo Meters with False Easting of 2,000,000 $\mathrm{m}$ and False Northing of 5,000,000 $\mathrm{m}$ in the transformation parameters. The RSO map projection system provides an optimum solution to reduce distortion whilst remaining conformal to suit the coordinate's computation and cadastral mapping [21].

The mission time for TRMM is measured based on Coordinated Universal Time (UTC) [22]. Therefore, it needs to be adjusted to Malaysian local time: UTC + 0800 hour [23]. The acquired data at similar instants in the local time were stratified by the local standard time at a 3-hourly time interval.

Accumulation maps of TMPA 3B42 v7 have total rainfalls computed over time for a given grid cell of continuous data variables with few or no gaps. Since the gaps are treated as the same values as 0 , this may result in low bias in data with gaps [22]. Rainfall accumulation maps are generated from the website in Network Common Data (NetCDF) format. NetCDF is an interface for array-oriented data access that presents data access libraries freely for various programming languages such as C, C++, Fortran, and Java [24]. The gridded data files containing both the geographical coordinates and the accumulated rainfall depth for each grid cells are imported into the GIS platform. Each grid cell has a fine spatial resolution of $0.25^{\circ} \times 0.25^{\circ}$ scale at approximate distance of $15^{\prime} \times 15^{\prime} \approx 27.73 \mathrm{~km} \times 27.73 \mathrm{~km}$. The TMPA grid cell maps have 20 cells being considered on the SSB as labelled in Figure 2. By using ArcGIS, the retrieved rainfall accumulation maps are converted as point maps to obtain rainfall accumulation depth for each grid cell.

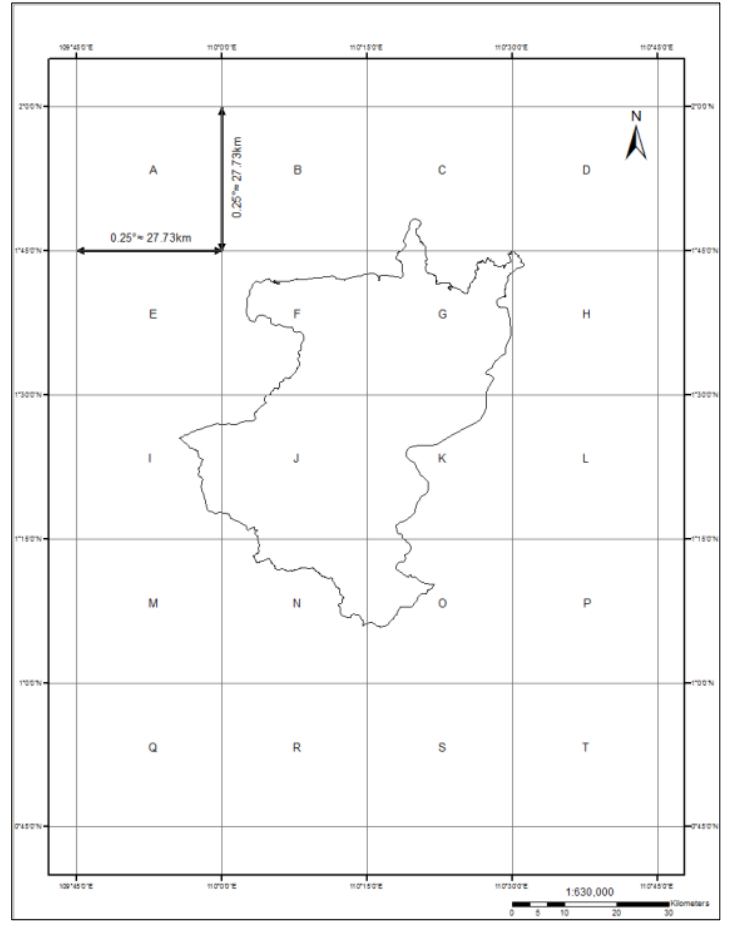

Figure 2. TMPA grid cells map layered on SSB

\section{Results and discussion}

\subsection{Assessment of TMPA 3B42 v7}

\subsubsection{Validation of TMPA $3 B 42 v 7$ with rain gauge}

Percentage Errors (PE) are differences between satellite algorithm estimates and rain gauge observations for individual stations. The output values can be either positive or negative values, where negative PE values would indicate underestimation of rainfall depth while positive PE values would indicate otherwise. The relative bias (RB) describes the systematic bias of SBP. Negative percentage of $\mathrm{RB}$ indicates underestimation by TMPA $3 \mathrm{~B} 42$ v7 while, positive percentage of $\mathrm{RB}$ means overestimation by TMPA 3B42 v7. The root mean square error (RMSE) is used to measure the magnitude of the average error. Due to the RMSE values being inappropriate to define mean error and easily misinterpreted [25], therefore the normalized root mean square error (NRMSE), or also known as the relative RMSE, is introduced. The statistic index is used to measure the reliability of the satellite algorithm precipitation estimates. The recommended value of NRMSE is $(<50 \%)$ [26]. The Pearson's Correlation Coefficient (CC) is used to measure the agreement between precipitation estimations from satellite and observations from rain gauge. Ideally the values of $\mathrm{CC}$ range from $(-1<\mathrm{CC}<+1)$. The $\mathrm{CC}$ value of +1 specifies perfect positive fit while values of -1 indicate a perfect negative fit. If there is no linear correlation or weak linear correlation then the $\mathrm{CC}$ is near 0 .

For validation of the TMPA 3B42 v7, rainfall observations from the ground surface (rain gauge) that 
are located within each grid cell are compared with the rainfall estimation from satellite (TMPA 3B42 v7). The accuracy of the TRMM satellite algorithm estimates are determined by the NRMSE and the CC statistic indexes are used in this study. When the estimates are deem reliable, then it is considered suitable to represent the spatial distribution of rainstorms.

The following continuous statistical methods by [9] are used to evaluate the quality of the TMPA 3B42 v7 3hourly precipitation:

$$
\begin{aligned}
& P E=\frac{\left(P_{o b s}-P_{e s t}\right)}{P_{o b s}} \times 100 \\
& R B=\frac{\sum_{i=l}^{N}\left(P_{e s t}-P_{o b s}\right)}{\sum_{i=1}^{N} P_{o b s}} \times 100 \\
& R M S E=\sqrt{\frac{\sum_{i=1}^{N}\left(P_{e s t}-P_{o b s}\right)^{2}}{N}} \\
& N R M S E=\frac{R M S E}{\left(\frac{\sum_{i=1}^{N} P_{o b s}}{N}\right)} \times 100 \\
& C C=\frac{\operatorname{Cov}\left(P_{o b s}, P_{e s t}\right)}{\sigma\left(P_{o b s}\right) \cdot \sigma\left(P_{e s t}\right)}
\end{aligned}
$$

where, $\operatorname{Cov}=$ Covariance; $\sigma\left(P_{o b s}\right)=$ Standard deviation of rain accumulation from ground surface observations (rain gauge); $\sigma\left(P_{\text {est }}\right)=$ Standard deviation of rain accumulation from satellite estimations (TMPA 3B42 v7); $P_{o b s}=$ Precipitation accumulation from ground surface observations (rain gauge); and $P_{\text {est }}=$ Precipitation accumulation from satellite estimations (TMPA $3 \mathrm{~B} 42$ v7).

\subsubsection{Performance assessment using continuous statistics}

Presented in Table 3, the percentage error assessment can be observed for TMPA 3B42 v7 during extreme rainfall events.

The PE between ground surface and satellite observations for storm period: a) Feb 01-07, 2003 ranges from $(-49.38$ to +42.12$) \%$, b) Jan 23-29, 2004 ranges from $(-2.75$ to +50.11$) \%$, c) Jan 05-11,2009 ranges from $(-66.71$ to +52.09$) \%$, and d) Jan 24-30, 2009 ranges from $(-46.83$ to +19.49$) \%$ (Table 3$)$.

Table 3. Percentage error assessments for storm events in

\begin{tabular}{|c|c|c|c|c|}
\hline $\begin{array}{l}\text { Kuching } \\
\text { Airport }\end{array}$ & 31.14 & 32.38 & 15.04 & 8.84 \\
\hline $\mathrm{Bau}$ & 13.13 & 9.67 & 45.34 & $-28.53 *$ \\
\hline Buan Bidi & NA & NA & 39.85 & $-28.28 *$ \\
\hline Krokong & 3.60 & $-0.80^{*}$ & 38.8 & $-19.08 *$ \\
\hline $\begin{array}{l}\text { Kampung } \\
\text { Monggak }\end{array}$ & $-7.17 *$ & 5.83 & 39.33 & $-32.37 *$ \\
\hline $\begin{array}{l}\text { Kampung } \\
\text { Opar }\end{array}$ & 17.05 & 34.00 & 52.09 & $-37.57^{*}$ \\
\hline $\begin{array}{l}\text { Siniawan } \\
\text { Water } \\
\text { Works }\end{array}$ & 19.17 & 14.60 & 35.46 & 11.99 \\
\hline $\begin{array}{l}\text { Buntal } \\
\text { DID }\end{array}$ & $-24.63 *$ & 24.73 & 32.24 & $-11.12^{*}$ \\
\hline $\begin{array}{l}\text { Kuching } \\
\text { Saberkas }\end{array}$ & $-10.80 *$ & 22.60 & 35.68 & $-4.15^{*}$ \\
\hline $\begin{array}{l}\text { Kuching } \\
\text { Third Mile }\end{array}$ & 6.86 & 33.55 & $-14.87^{*}$ & $-27.79 *$ \\
\hline Siol JPS & NA & 30.72 & 27.33 & $-34.99 *$ \\
\hline
\end{tabular}
each gauging station

\section{Storm Period}

\begin{tabular}{|c|c|c|c|c|c|}
\hline 14 & $\begin{array}{l}\text { Telok } \\
\text { Assam }\end{array}$ & 9.06 & $-2.75^{*}$ & 30.70 & $-16.06^{*}$ \\
\hline 15 & Ulu Maong & 4.20 & 30.15 & 13.99 & $-25.79 *$ \\
\hline 16 & $\begin{array}{l}\text { Semariang } \\
\text { Fisheries }\end{array}$ & $-39.06^{*}$ & 30.09 & $-40.70 *$ & 14.60 \\
\hline 17 & Rampangi & $-49.38 *$ & 26.04 & 26.89 & $-16.98^{*}$ \\
\hline 18 & $\begin{array}{l}\text { Bako } \\
\text { Causeway }\end{array}$ & $-4.94 *$ & 30.47 & 20.74 & $-18.87^{*}$ \\
\hline 19 & $\begin{array}{l}\text { Sungai } \\
\text { China }\end{array}$ & $-10.18^{*}$ & 20.59 & $-66.71 *$ & $-29.66^{*}$ \\
\hline 20 & Matang & 5.86 & 19.23 & 35.94 & 1.86 \\
\hline 21 & $\begin{array}{l}\text { Sungai } \\
\text { Rayu }\end{array}$ & $-35.94 *$ & 9.66 & $-1.56^{*}$ & $-46.83 *$ \\
\hline 22 & $\begin{array}{l}\text { Kampung } \\
\text { Sagah }\end{array}$ & NA & NA & 38.42 & $-30.31 *$ \\
\hline 23 & Sebubut & $-7.93 *$ & 9.94 & 22.79 & $-17.28 *$ \\
\hline 24 & Padawan & 6.52 & 50.11 & $-5.47 *$ & $-33.15^{*}$ \\
\hline 25 & Semban & 4.85 & 29.11 & 30.99 & 19.49 \\
\hline
\end{tabular}

\begin{tabular}{llll}
\hline Feb 01- & Jan 23- & Jan 05- & Jan 24- \\
07, & 29, & 11, & 30, \\
2003 & 2004 & 2009 & 2009
\end{tabular}

\begin{tabular}{llllll}
\cline { 3 - 5 } No. & $\begin{array}{l}\text { Station } \\
\text { Name }\end{array}$ & PE / \% & PE / \% & PE / \% & PE / \% \\
\hline 1 & $\begin{array}{l}\text { Batu } \\
\text { Kitang }\end{array}$ & 34.31 & 43.25 & 25.45 & 15.79 \\
2 & $\begin{array}{l}\text { Kampung } \\
\text { Git }\end{array}$ & 42.12 & 42.54 & $-2.07 *$ & 1.88
\end{tabular}

Table 3. (continued)

$* \%$ value is overestimation by TMPA $3 \mathrm{~B} 42 \mathrm{v} 7$ 
Referring to Table 4, the RB indicates systematic underestimations conducted by the TMPA $3 \mathrm{~B} 42 \mathrm{v} 7$ is observed during storm periods: Feb 01-07, 2003, Jan 2329, 2004 and Jan 05-11, 2009, meanwhile systematic overestimation by TMPA 3B42 v7 is observed during storm period: Jan 24-30, 2009. The magnitude of average error and the relative RMSE are the highest during the storm period of Jan 05-11, 2009 (RMSE = $215.4 \mathrm{~mm}$, NRMSE $=37.2 \%$ ). However, the RMSE does not affect the statistical correlation and all storm events have a positive fit of linear correlation whereby the storm period from Jan 23-29, 2004 has the nearest to perfect linear correlation $(\mathrm{CC}=0.8)$.
Table 4. Statistical assessments for storm events

\begin{tabular}{|c|c|c|c|c|}
\hline & \multicolumn{4}{|c|}{ Storm Period } \\
\hline & $\begin{array}{l}\text { Feb 01- } \\
\text { 07, 2003 }\end{array}$ & $\begin{array}{l}\text { Jan 23- } \\
29 \text {, } \\
2004\end{array}$ & $\begin{array}{l}\text { Jan 05- } \\
11,2009\end{array}$ & $\begin{array}{l}\text { Jan 24- } \\
30,2009\end{array}$ \\
\hline RB / \% & -2.7 & -23.8 & -26.1 & 13.6 \\
\hline $\begin{array}{l}\text { RMSE / } \\
\text { mm }\end{array}$ & 126.2 & 176.5 & 215.4 & 75.4 \\
\hline $\begin{array}{l}\text { NRMSE } \\
/ \%\end{array}$ & 22.1 & 27.9 & 37.2 & 22.5 \\
\hline $\mathrm{CC}$ & 0.3 & 0.8 & 0.6 & 0.7 \\
\hline
\end{tabular}

To assess the performance of the satellite estimates during heavy precipitation for different elevations, the datasets are classified into 2 groups: 1) for lower altitude of ( $<40$ MASL) elevation (Table 5); and 2) low to medium altitude of ( $>40$ MASL) elevation (Table 6 ).

For lower altitudes, the RB indicates systematic overestimations by TMPA $3 \mathrm{~B} 42 \mathrm{v} 7$ is observed during storm periods: Feb 01-07, 2003 and Jan 24-30, 2009 but systematic underestimations for the rest of the storm periods (Table 5). The RMSE and the NRMSE are the highest during the storm period of Jan 05-11, 2009, and followed by Jan 23-29, 2004, Feb 01-07, 2003 and Jan 24-30, 2009. All storm events have a positive fit of linear correlation, except for the event during Feb 01-07, 2003 which has the weakest relation $(\mathrm{CC}=-0.3)$, and during the storm period from Jan 23-29, 2004 has the nearest to perfect linear correlation $(\mathrm{CC}=0.8)$.

For low to medium altitude, the RB is within $( \pm 33.4$ $\%$ and indicates a majority of systematic underestimations by TMPA $3 \mathrm{~B} 42 \mathrm{v} 7$ for the rest of the storm periods, except for storm period: Jan 24-30, 2009 (Table 6). The magnitude of average error and the relative RMSE are the highest during the storm period of Jan 05-11, $2009(\mathrm{RMSE}=236.5 \mathrm{~mm}, \mathrm{NRMSE}=36.7 \%)$ and has the best fit of correlation $(\mathrm{CC}=0.9)$. Notably, a higher $\mathrm{CC}$ value also leads to a larger RMSE value in this case. However, more uniform and positive correlation for all storm events can be observed for low to medium altitude ( $>40$ MASL). Furthermore, all random errors of the TMPA 3B42 v7 estimations are $(<50 \%)$ of the measured rain gauge observations. Therefore, the satellite algorithm estimates are deemed reliable. These findings also suggest that satellite algorithm estimations from TMPA 3B42 v7 are suitable for low to medium ground elevations ( $>40$ MASL) during extreme rainfalls. This proves that TMPA 3B42 v7 estimations have better agreement with gauging observations for higher ground levels than lower levels, which matches with other's study findings [27-29]. 
Table 5. Statistical assessments for elevation $<40$ MASL for storm events

\section{Storm Period}

$\begin{array}{llll}\text { Feb 01- } & \text { Jan 23- } & \text { Jan 05- } & \text { Jan 24- } \\ \text { 07, 2003 } & \text { 29, } & \text { 11, 2009 } & \text { 30, 2009 }\end{array}$

\begin{tabular}{lllll}
$\mathbf{R B} / \%$ & 0.4 & -26.7 & -19.2 & 17.5 \\
$\begin{array}{l}\mathbf{R M S E} / \\
\mathbf{m m}\end{array}$ & 150.2 & 184.7 & 197.2 & 84.9 \\
$\begin{array}{l}\text { NRMSE } \\
/ \%\end{array}$ & 25.3 & 30.7 & 37.4 & 24.0 \\
$\mathbf{C C}$ & -0.3 & 0.8 & 0.6 & 0.6 \\
\hline
\end{tabular}

Table 6. Statistical assessments for elevation $>40$ MASL for storm events

Storm Period

\begin{tabular}{lllll}
\hline & $\begin{array}{l}\text { Feb 01- } \\
\mathbf{0 7 , 2 0 0 3}\end{array}$ & $\begin{array}{l}\text { Jan 23- } \\
\mathbf{2 9} \\
\mathbf{2 0 0 4}\end{array}$ & $\begin{array}{l}\text { Jan 05- } \\
\mathbf{1 1 , 2 0 0 9}\end{array}$ & $\begin{array}{l}\text { Jan 24- } \\
\mathbf{3 0 , 2 0 0 9}\end{array}$ \\
& & & & \\
$\mathbf{R B} / \mathbf{\%}$ & -6.7 & -20.5 & -33.4 & 7.8 \\
$\begin{array}{l}\text { RMSE } / \\
\text { mm }\end{array}$ & 89.2 & 165.1 & 236.5 & 61.3 \\
$\begin{array}{l}\text { NRMSE } \\
\text { / \% }\end{array}$ & 16.4 & 24.6 & 36.7 & 19.7 \\
$\mathbf{C C}$ & 0.7 & 0.8 & 0.9 & 0.7 \\
\hline
\end{tabular}

Generally, overall results indicate the tendency for underestimations by TMPA 3B42 v7 when compared to rain gauge observations during seasonal heavy precipitation, regardless of varying elevations. The differences between ground surface observations and satellite estimations are anticipated because the TMPA $3 B 42$ v7 satellite grid are accumulated average SBP product with a spatial resolution of $27.73 \mathrm{~km}$ by 27.73 $\mathrm{km}$ distance, but compared to the ground observations, which is a measurement from single point rain gauge.

\subsection{Spatial distribution of rainstorms}

Spatial distribution of rain accumulation from ground surface observations (rain gauge) and satellite algorithm estimations (TMPA 3B42 v7) for the four rainstorm events are presented in Appendix A. Spatial interpolation by means of the Kriging estimation approach is used to represent the rainfall distribution during rainstorm events. Based on comparison of the rainfall maps, the locations of the storm eye for each storm period are quite similar. These results reinstate that the TRMM satellite algorithm plot has represented the spatial distribution of extreme rainfalls in SSB effectively.
Notably, for storm periods of Jan 05-11, 2009, the variability of the spatial distribution differs greatly between TMPA 3B42 v7 and rain gauge. The maximum rain accumulation during this period is recorded at 455.4 $\mathrm{mm}$ (TMPA 3B42 v7) and $950.5 \mathrm{~mm}$ (rain gauge). A large difference of TMPA $3 \mathrm{~B} 42 \mathrm{v} 7$ and rain gauge estimation $(-495.1 \mathrm{~mm})$ indicates a significant gap between the two.

\section{Conclusion}

This paper compares the rainfall distribution from ground surface observations (rain gauge) and satellite algorithm estimations (TRMM). Precipitation accumulation for the 6-day duration during rainstorm events is retrieved from TMPA 3B42 v7 dataset. An investigation is then conducted to determine the suitability of TRMM satellite algorithm estimates to represent the distribution of extreme rainfalls in SSB.

Based on the investigation, the satellite algorithm datasets from TMPA 3B42 v7 are reliable and suitable for extreme rainfall estimations. Moreover, the TRMM satellite algorithm plots have also represented the spatial distribution of extreme rainfalls in SSB effectively. Nevertheless, precaution must be considered when using the data, where the results indicating the tendency of underestimations by TMPA 3B42 v7.

This research has utilized research method sourcing alternative data from public domain satellite (TRMM) that are accessible to public. Furthermore, the alternative method also provides the platform for innovative solutions to engineering and technology challenges that contribute to understanding the variation pattern of rain during extreme conditions. The findings are relevant to regions with limited gauging stations, but satellite algorithm estimates (TRMM) do not necessarily substitute the observations from rain gauge and is only useful for additional information or as an alternative data source. Hence, the accuracy and robustness of the TRMM satellite product needs to be further explored in hydrologic modelling which can determine theoretically ideal conditions.

\section{Acknowledgement}

This study was supported by the research fund, Dana Pelajar PhD (DPP) (Grant number F02/DPP64/1445/2016/11) of Universiti Malaysia Sarawak (UNIMAS). The TMPA 3B42 v7 precipitation datasets are provided by the NASA/Goddard Space Flight Center and PPS, which develop and compute the TMPA $3 \mathrm{~B} 42$ v7 dataset as a contribution to TRMM, and archived at the NASA GES DISC. The base map and rain gauge datasets are acquired from the DID. 


\section{References}

1. A. Mair \& A. Fares. Comparison of rainfall interpolation methods in a mountainous region of a tropical island. J. Hydrol. Eng., 16(4), 371-383. (2011)

2. F. Othman, A. Akbari, \& A. A. Samah. Spatial rainfall analysis for an urbanized tropical river basin. Int. J. Phys. Sci., 6(20), 4861-4868. (2011)

3. T. V. Omotosho, J. S. Mandeep, M. Abdullah, \& A. T. Adediji. Distribution of one-minute rain rate in Malaysia derived from TRMM satellite data. In Ann. Geophys. 31 (11), 2013-2022. Copernicus GmbH. (2013)

4. C. J. Wiesner. Hydrometeorology. London, United Kingdom: Chapman and Hall Ltd. (1970)

5. G. J. Huffman, R. F. Adler, D. T. Bolvin, \& E. J. Nelkin. Satellite Rainfall Applications for Surface Hydrology. In M. Gebremichael \& F. Hossain (Eds.), (pp. 3-22). Dordrecht: Springer Netherlands. (2010).

6. S. I., Khan, Y., Hong, J. J. Gourley, M. U. K. Khattak, B. Yong, \& H. J. Vergara. Evaluation of three high-resolution satellite precipitation estimates: Potential for monsoon monitoring over Pakistan. Adv. Space Res., 54(4), 670-684. (2014)

7. A. Ochoa, L. Pineda, P. Crespo, \& P. Willems. Evaluation of TRMM 3B42 precipitation estimates and WRF retrospective precipitation simulation over the Pacific-Andean region of Ecuador and Peru. Hydrol. Earth Syst. Sci., 18(8), 3179-3193. (2014)

8. P. Salio, M. P. Hobouchian, Y. García Skabar, \& D. Vila. Evaluation of high-resolution satellite precipitation estimates over southern South America using a dense rain gauge network. Atmos. Res., 163, 146-161. (2015)

9. M. L. Tan, A. L., Ibrahim, D. Zheng, A. P. Cracknell, V. Chaplot, 2015. Evaluation of Six HighResolution Satellite and Ground-Based Precipitation Products over Malaysia. Remote Sens., 7(2), 15041528. (2015)

10. F. A. Semire, R. Mohd-Mokhtar, W. Ismail, N. Mohamad, \& J. S. S. Mandeep. Ground validation of space-borne satellite rainfall products in Malaysia. Adv. Space Res., 50(9), 1241-1249. (2012)

11. S. Chen, P. E. Kirstetter, Y. Hong, J. J. Gourley, Y. D. Tian, Y. C. Qi, Q. Cao, J. Zhang, K. Howard, J.J. $\mathrm{Hu}, \&$ X.W. Xue. Evaluation of spatial errors of precipitation rates and types from TRMM spaceborne radar over the southern CONUS. J. Hydrometeorol., 14(6), 1884-1896. (2013)

12. K. K., Kuok, Z. Z., Liew, \& P. Chiu. Flood map development by coupling satellite maps and threedimensional drafting software: Case study of the Sarawak River Basin. Water SA, 39(1), 175-182. (2013)

13. Y. H. Lim, \& L. M. Lye. Regional flood estimation for ungauged basins in Sarawak, Malaysia. Hydrol. Sci. J., 48(1), 79-94. (2003)

14. S. L. Muhammad, W. A. W. Z. Abidin, W. Y. Chai, A. Baharun, \& T. Masri. Development of Wind Mapping Based on Artificial Neural Network (ANN) for Energy Exploration in Sarawak. Int. J. Renew. Energy Res. (IJRER), 4(3), 618-627. (2014)

15. SPU (State Planning Unit Sarawak). All about Sarawak.

http://www.spu.sarawak.gov.my/geography.html (2011) [Accessed on 19 April 2016]

16. DID (Department of Irrigation and Drainage), Sarawak Hydrological Year Book 2014 Volume 41. Kuching, 497p. (2016)

17. WMO (World Meteorological Organization), Guide to Hydrometeorological Practices, WMO 168. TP.82. World Meteorological Organization. Geneva, Switzerland, 323 pp. (1965)

18. B. E. Vieux. Distributed Hydrologic Modeling Using GIS. $2^{\text {nd }}$ Edition, Vol. 48. Springer Netherlands. (2004)

19. D. Y. S. Mah, S. H. Lai, R. Aldrino, \& F. J. Putuhena. Investigative modelling of the flood bypass channel in Kuching, Sarawak, by assessing its impact on the inundations of Kuching-Batu KawaBau Expressway. Struct. Infrastruct. E., 8(7), 705714. (2010)

20. A. Dindang, A. Taat, E. B. Phuah, A. B. M. Alwi, A. A. Mandai, S. F. Adam, F.S. Othman, D. N. Awang Bima, D. Lah. Statistical and trend analysis of rainfall data in Kuching, Sarawak from 1968-2010. Malaysian Meteorological Department (MMD), Ministry of Science, Technology and Innovation (MOSTI). (2013)

21. JUPEM (Jabatan Ukur dan Pemetaan Malaysia), Garis Panduan Mengenai Sistem Rujukan Koordinat di dalam Penggunaan Global Navigation Satellite System (GNSS) Bagi Tujuan Ukur dan Pemetaan. JUPEM, Malaysia. (2009)

22. GSFC (Goddard Space Flight Center). Tropical Rainfall Measuring Mission Office. [Online]. http://trmm-

fc.gsfc.nasa.gov/trmm_gv/information/brochure/broc hure.html. (2016). [Accessed on 20 January 2016]

23. H. Varikoden, B. Preethi, A. A. Samah, \& C. A. Babu, Seasonal variation of rainfall characteristics in different intensity classes over Peninsular Malaysia. J. Hydrol., 404(1-2), 99-108. (2011)

24. R. Rew, G. Davis, S. Emmerson, H. Davies, E. Hartnett, D. Heimbigner, \& W. Fisher. Introduction and Overview. [Online]. From: http://www.unidata.ucar.edu/software/netcdf/docs/in dex.html (2016). [Accessed on 18 May 2016]

25. T. Chai, \& R. R. Draxler, Root mean square error (RMSE) or mean absolute error (MAE)? -Arguments against avoiding RMSE in the literature. Geosci. Model Dev., 7(3), 1247-1250. (2014).

26. S. H. Franchito, V. B. Rao, A. C. Vasques, C. M. E. Santo, \& J. C. Conforte. Validation of TRMM precipitation radar monthly rainfall estimates over Brazil. J. Geophys. Res. - Atmos., 114(2). (2009).

27. F. A. Hirpa, M. Gebremichael, \& T. Hopson. Evaluation of high-resolution satellite precipitation products over very complex terrain in Ethiopia. J. Appl. Meteorol. Climatol., 49(5), 1044-1051. (2010)

28. N. Y. Krakauer, S. M. Pradhanang, T. Lakhankar, \& A. K. Jha. Evaluating satellite products for 
precipitation estimation in mountain regions: A case study for Nepal. Remote Sens., 5(8), 4107-4123. (2013)

29. S. Rana, J. McGregor, \& J. Renwick. Precipitation Seasonality over the Indian Subcontinent: An Evaluation of Gauge, Reanalyses, and Satellite Retrievals. J. Hydrometeorol., 16(2), 631-651. (2015) 


\section{Appendix}

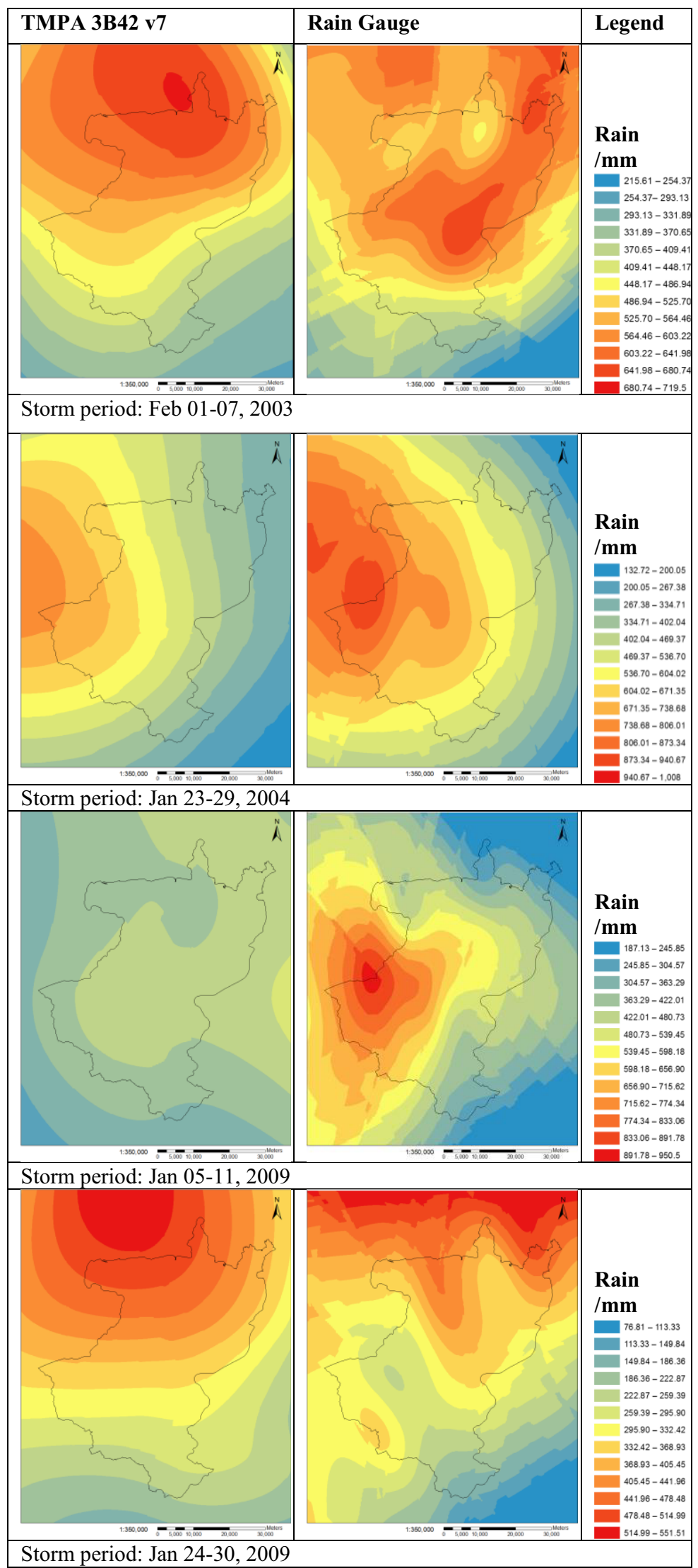

Appendix A. Spatial distribution of rainstorms over SSB 